\title{
Physicochemical composition and antioxidants of buriti (Mauritia flexuosa Linn. F.) - pulp and sweet
}

\author{
Nara Rúbia Rodrigues Nascimento-Silva ${ }^{1, *}$ \\ http://orcid.org/0000-0003-1318-9298 \\ Flávio Alves Silva ${ }^{1}$ \\ http://orcid.org/0000-0002-3619-755X \\ Mara Reis Silva ${ }^{2}$ \\ http://orcid.org/0000-0002-2343-6267 \\ ${ }^{1}$ Department of Food Engineering, School of Agronomy, Federal University of Goiás, Goiânia, Brazil; \\ ${ }^{2}$ Faculty of Nutrition - Federal University of Goiás, Goiânia, Brazil; \\ *Correspondence: nara.n.nutri@gmail.com
}

Received: 2019.08.21; Revised: 2019.10.21; Accepted: 2019.11.13; Published: 2020.01.01

Highlights: The present work emphasizes the importance of knowledge of the proximal composition and the bioactive compounds of buriti pulp and its sweet obtained from different locations of Brazil, aiming at the valorization of the native fruit. This article is the first to report the concentration of bioactive compounds in buriti sweet and one of the few to describe their nutritional value. The paper should be of interest to readers in the of area "assessment of the nutritional quality of fruit products".

Section: This paper was submitted in Food science, a section of the J. Bioen Food Sci.

Competing interests: There is not conflict of interest in the research conducted.

Funding: The research received financial aind from CNPq (National Council for Scientific and Technological Development) - Brazilian research supporting foundation.

Citation as (APA): Nascimento-Silva, N.R.R., Silva, F.A., \& Silva, M.R. (2020). Physicochemical composition and antioxidants of buriti (Mauritia flexuosa Linn. F.) - pulp and sweet. Journal of bioenergy and food science, 7(1), e2792019JBFS. doi: 10.18067/jbfs.v7i1.279

Edited by Dr. Victor Hugo Gomes Sales - Federal Institute of Amapá, Macapá-AP, Brazil.

Review processes: 2792019R01 | 2792019R02 
ABSTRACT - Buriti pulp has an elevated nutritional value and commercial potential, mainly because of its significant amounts of bioactive compounds. The objective of this research was to evaluate the physicochemical characteristics, the antioxidant capacity, and bioactive compounds of buriti pulps and sweets obtained from the Brazilian states of Goiás, Tocantins and Para. The fruits obtained from Tocantins and Para presented greater lipid and energy contents. After processing, the sweets showed reductions in the protein, lipid, fiber and bioactive compound contents. The antioxidant activities and total phenolic compound contents were more significant in the pulp and sweets from Goiás. There was a strong correlation between the phenolic compounds and the antioxidant activity. The total carotenoid content was greater in the buriti pulp and sweet from Tocantins but an $80 \%$ reduction in the bioactive compounds was observed in all the sweets produced. Thus, it was concluded that the origin of the fruit influenced its chemical composition and the antioxidant activity. However fruits and sweets can still be considered good dietary sources of bioactive compounds especially carotenoids.

Keywords: Carotenoids. Polyphenols. Native fruits. Nutrients

\section{INTRODUCTION}

Buriti (Mauritia flexuosa Linn. F.) is the fruit of a palm tree from the Arecaceae family, which can be found in the Savanna and Amazonian biomes (Roucoux et al., 2013). This palm tree grows in pathways, woodlands, on the banks of rivers, streams and lakes and close to springs. Regarding the development and maturation, the fruit is considered climacteric and its ideal harvesting point occurs 210 days after the anthesis (Milanez et al., 2016).

The palm can be used for ornamental and medicinal purposes, while buriti pulp is used as food for many indigenous and rural groups, consumed in the form of jams, jellies, juices and ice creams (Gomes et al., 2011; Virapongse, 2017). Buriti sweet is one of the most common forms of commercializing the fruit and is traditionally made by reducing a conserve of the fruit prepared with fruit pulp and sugar in a 1:1 proportion (Medeiros, 2011).

The fruit contains phenolic compounds and can be considered as a source of carotenoids, especially due to the elevated $\beta$-carotene content (Cândido et al., 2015; (Milanez et al., 2018; Mezzomo \& Ferreira, 2016), which has recognized nutritional importance, being presented as a viable alternative to reduce the incidence of xerophthalmia, besides influencing reactions involving oxidative processes and reducing the risk of developing cardiovascular diseases (Neri-Numa et al., 2018). However, climatic and geographical variations can influence the chemical composition of native fruits due to differences in the plant development conditions (Cândido et al., 2015).

Mariath et al. (1989) proved the effectiveness of buriti sweet in restoring the vitamin A reserves in the liver and in the treatment of xerophthalmia in children between 3 and 12 years old, living in the Northeast of Brazil. No reports were found in the specialized literature concerning research about the influence of the region that produced the buriti on the chemical composition of the sweet. Hence research on the nutritional composition of fruits from different biomes and the losses occurring during processing of the sweet could contribute to a scientific collection concerning the fruit and preservation of the biomes. Thus, the objective of this work was to evaluate the chemical and physical characteristics and the bioactive compounds of buriti pulp and its sweet obtained from three locations representing the Brazilian Savanna and Amazonas and the transition between these two Brazilian biomes.

\section{MATERIAL AND METHODS}

\section{a) Collection of the fruits and obtaining the pulp}

The buriti fruits (Mauritia flexuosa Linn f.) were collected in Goiás (S $16^{\circ} 35$ 634'; W 49 22 518'; altitude $771 \mathrm{~m}$ ), Tocantins (S 06 27 187'; W 48 32 444'; altitude $140 \mathrm{~m}$ ) and Pará (S $06^{\circ} 19$ 598'; W48 28 668'; altitude $127 \mathrm{~m}$ ) during the months of November and December of 2017. The state of Goiás is occupied by the Savanna biome, Pará is located in the Amazonian biome and 
Tocantins is considered to be a geographical transition region between the Savanna biome and the Amazonian Forest (Saito, 2006; Silva, 2007). Between 90 and $120 \mathrm{~kg}$ of fruit were collected from each region. After harvesting the fruits were placed in plastic boxes and transported for sanitation and storage. The mature fruits were selected manually considering their size, color, state of maturation, uniformity of texture and the absence of blemishes and defects. The pulps were extracted manually, conditioned in low density polyethylene bags and frozen at $-18 \stackrel{\circ}{\circ}$ until the moment of the analyses and elaboration of the sweets. The physical and chemical analyses were carried out in the Nutrition and Food Analysis Laboratory of the Faculty of Nutrition of the Federal University of Goiás.

\section{b) Elaboration of the sweet}

The buriti pulp was thawed in the refrigerator for 12 hours and the sweets formulated according to the methodology described by Medeiros (2011). The sweets were prepared with buriti from each region (Goiás, Tocantins and Pará).The buriti pulp and sugar were used in a 1:1 proportion and the mixtures boiled for 16 minutes until they reached $82{ }^{\circ}$ Brix. The sweets were then transferred to rectangular $(15 \times 10 \mathrm{~cm})$ high density polyethylene containers, lined with a transparent PVC film and maintained at room temperature. After 24 hours the sweets were cut into cubes, which were wrapped in transparent PVC film and aluminum foil and frozen at $-18 \stackrel{\circ}{ } \mathrm{C}$ until analyzed (Figure 1).

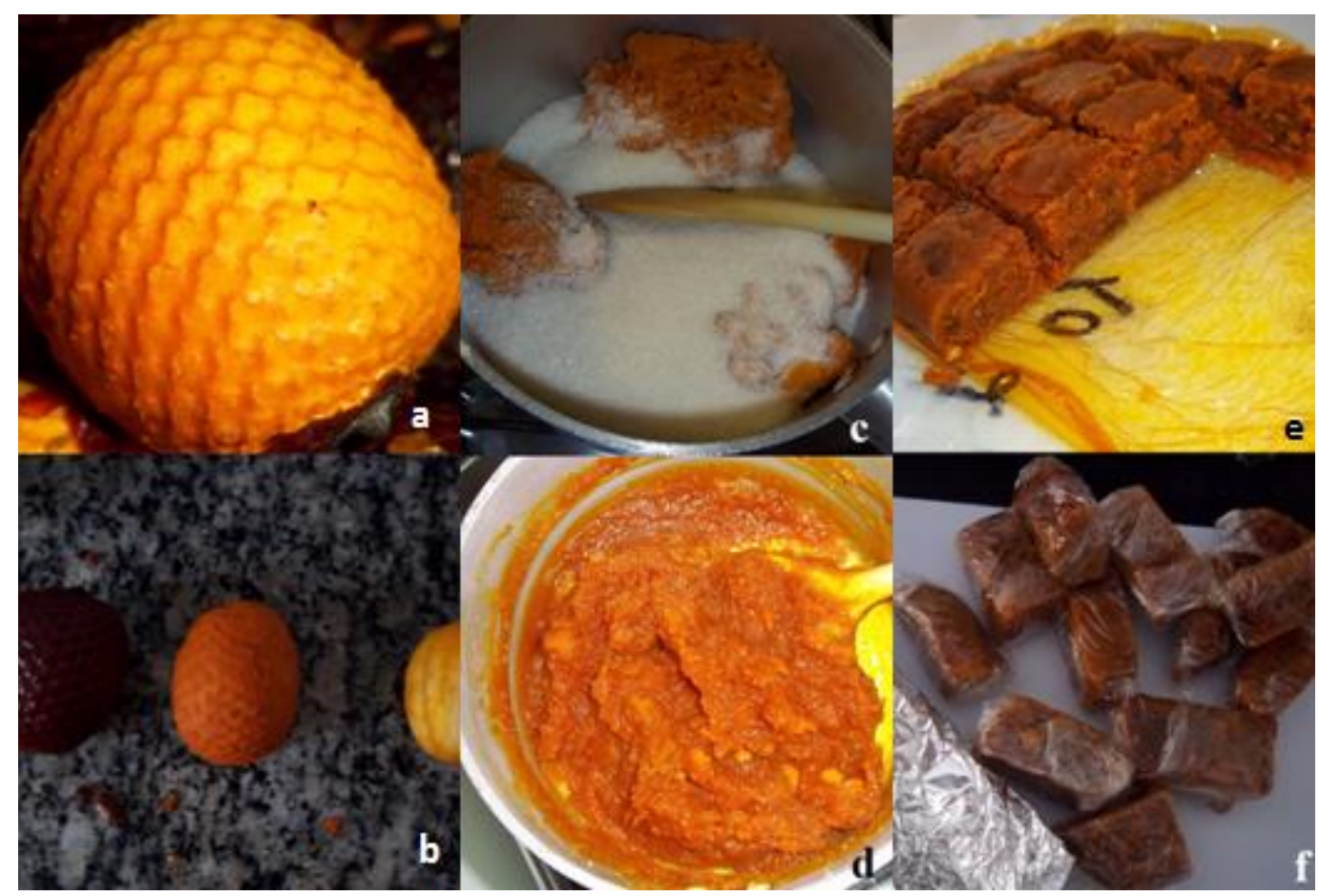

Figure 1 Buriti fruit $(A$ and $B)$, buriti sweet during processing $(C$ and $D)$ and ready-to-eat buriti sweet ( $E$ and $F$ ).

a,b buriti fruit; ${ }^{c, d}$ buriti sweet during processing; ${ }^{e, f}$ ready-to-eat buriti sweet

\section{c) Physical and chemical analyses and proximate composition}

The physical analyses were carried out according to Vera et al. (2005), selecting 30 fruits at random to determine mass and yield (10 repetitions) with the aid of a semi-analytical balance. The dimensions were determined using a Vernier Caliper Mitutoyo $150 \mathrm{~mm}$ x 6" pachymeter. The percent yield in pulp was obtained by multiplying the mass of pulp by 100 and dividing the result by the total mass of the fruit. With regard to the sweet, the final weight of the ready-to-eat product was multiplied by 100 and the result divided by the sum of the mass of pulp plus the mass of sugar.

The titratable acidity was determined using the neutralization volumetry technique with 
standard sodium hydroxide $(\mathrm{NaOH})$ solution of $0.1 \mathrm{~N}$ and expressed as a percentage of citric acid by the method 016 / IV (IAL, 2008); the pH was estimated electronically by direct potentiometry using $5.0 \mathrm{~g}$ of sample after stirring (AOAC, 2012); and the soluble solids were determined using a digital refractometer and expressed in ${ }^{\circ}$ Brix (IAL, 2008).

The proximate composition was carried out according to the methodology described by AOAC (2012). The moisture content was determined by gravimetric method at temperature of $105^{\circ} \mathrm{C}$ (method No. 934.06). The total nitrogen content was quantified using the micro-Kjeldahl method followed by conversion of the crude protein using a factor of 6.25 (method No. 920.152). The total lipid content was determined following the methodology of Bligh and Dyer (1959), while the fixed mineral residue were measured after the incineration of the samples at $550{ }^{\circ} \mathrm{C}$ (method No. 940.26). For dietary fiber it was used the enzymic-gravimetric method of Prosky et al. (1988). The carbohydrate content was calculated by difference, subtracting the sum of the values obtained for moisture, protein, lipids, ashes and fiber from 100. The Atwater factors were used to determine the total energy value as follows: $4 \mathrm{kcal} / \mathrm{g}, 4 \mathrm{kcal} / \mathrm{g}$ and $9 \mathrm{kcal} / \mathrm{g}$ for proteins, carbohydrates and lipids, respectively.

\section{d) Extraction}

The extracts of the buriti pulps and sweets were prepared for the determinations of the total phenolic compounds and antioxidants (ABTS, FRAP and DPPH• radicals) using $0.1 \mathrm{~g}$ of sample and adding $0.5 \mathrm{~mL}$ ethyl alcohol and $0.5 \mathrm{~mL}$ ultrapure water. The samples were then defatted using three successive washings with $1.0 \mathrm{~mL}$ hexane. For each washing, the samples were homogenized with a vortex for $30 \mathrm{sec}$ and then centrifuged at $5,000 \mathrm{rpm}$ for $5 \mathrm{~min}$ at $18{ }^{\circ} \mathrm{C}$ to separate the phases, discarding the supernatant with the hexane. After the third washing, the residue containing the ethanol and water was added to $1.0 \mathrm{~mL}$ of a solution containing acetone, acetic acid and ultrapure water in the proportions of 70:0.5:29.5, homogenized using a vortex for $30 \mathrm{sec}$ followed by ultrasound for $5 \mathrm{~min}$ at $37^{\circ} \mathrm{C}$, and then centrifuged at $9,000 \mathrm{rpm}$ for $10 \mathrm{~min}$ at $18{ }^{\circ} \mathrm{C}$. The supernatant was collected and diluted to $10 \mathrm{~mL}$ with ultrapure water and used to determine the total phenolic compounds and antioxidant activity.

\section{e) Total phenolics}

The total phenolic compounds were quantified using the method described by Genovese et al. (2008). $0.25 \mathrm{~mL}$ of the extract was homogenized with $2.0 \mathrm{~mL}$ of ultrapure water and $0.25 \mathrm{~mL}$ of Folin-Ciocalteu reagent. After $3 \mathrm{~min}$ at room temperature, $0.25 \mathrm{~mL}$ saturated sodium carbonate solution was added, and the mixture placed at $37^{\circ} \mathrm{C}$ in a water bath for $30 \mathrm{~min}$. The absorbance was measured at $750 \mathrm{~nm}$ in a UV/visible spectrophotometer (V-630, Jasco). Results were expressed as mg of gallic acid equivalent (GAE) per $100 \mathrm{~g}$ of lyophilized sample. The results were expressed in milligrams of GAE (gallic acid equivalent) per $100 \mathrm{~g}$ of sample.

\section{f) Antioxidant activity}

The in vitro analyses for the antioxidant activity of the pulps and sweets were as follows: $\mathrm{DPPH} \cdot$ (2,2-diphenyl-1-picryl-hydrazil), ABTS [2,2 azinobis (3-ethylbenzothiazoline-6-sulfonic acid)] and the $\mathrm{Fe}^{3+}$ reducing capacity (FRAP). The capacity of the antioxidants to sequester the stable DPPH• radical was determined according to Brand-Williams et al. (1995). The trolox standard curve was built from the inhibition percentage versus the trolox concentration $(50 \mathrm{mg} / \mathrm{L}$ to $250 \mathrm{mg} / \mathrm{L}$ ) and the values were expressed in $\mu \mathrm{mol}$ of trolox equivalent per gram of sample $\mu \mathrm{mol}$ TE $\mathrm{g}^{-1}$ ). The Benzie and Strain method (1996) was used for the FRAP assay. Trolox was used as the standard for the calibration curve, in concentrations that varied from $100 \mu \mathrm{mol} / \mathrm{L}$ to $800 \mu \mathrm{mol} / \mathrm{L}$. The results were expressed in $\mu \mathrm{mol}$ of trolox equivalents per gram of sample $\left(\mu \mathrm{mol} T E \mathrm{~g}^{-1}\right)$. The ABTS method was carried out according to the methodology described by $R e$ et al. (1999). The

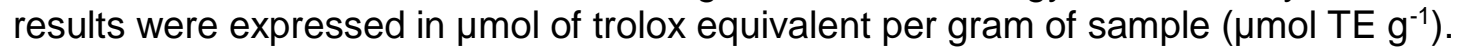

\section{g) Determination of the total carotenoids}

The total carotenoids were quantified according to the methods reported by Rodriguez- 
Amaya (2001), in triplicate. Initially, $150 \mathrm{mg}$ of BHT (butylated hydroxytoluene- di-terc-butyl methyl phenol) and $70 \mathrm{~mL}$ of chilled acetone were added to the sample, homogenized in a Walita multiprocessor for 2 min in four steps, being vacuum filtered at the end of each step. The final residue was discarded, and the total solution collected submitted to liquid-liquid partition using 100 $\mathrm{mL}$ hexane and sufficient distilled water to confer transparency to the solution. The water-acetone phase was discarded, and the hexane phase collected and diluted to $200 \mathrm{~mL}$ with hexane. Finally, readings were taken using a UV/Visible scanning spectrophotometer (V-630, Jasco) between 350 and $700 \mathrm{~nm}$. The total carotenoid content was determined using the highest value observed for absorbance.

\section{h) Statistical analysis}

The results were expressed as the mean and standard deviation and submitted to an analysis of variance and Tukey's means comparison test (ANOVA and Tukey at 5\% of probability). The statistical calculations were made with the aid of the IBM SPSS Statistics, version 20.

\section{RESULTS AND DISCUSSION}

\section{a) Physical and chemical analyses and proximate composition}

The fruits from Goiás present larger mass and longitudinal and transverse diameters, than the others regions. However, the yield of the pulp was similar between the fruits studied in our study and the literature data (Table 1).The mass and yield of the sweets elaborated with buriti pulp from different States were similar (Table 2).

Table 1 Physical and chemical characteristics of the buriti fruits from the Brazilian States of Goiás, Tocantins and Pará compared to the literature data.

\begin{tabular}{|c|c|c|c|c|c|c|}
\hline Characteristics & Mass (g) & $\begin{array}{l}\text { Longitudinal } \\
\text { diameter }(\mathrm{cm})\end{array}$ & $\begin{array}{c}\text { Transverse } \\
\text { diameter }(\mathrm{cm})\end{array}$ & $\begin{array}{c}\text { Yield in pulp } \\
(\%)\end{array}$ & $\mathrm{pH}$ & $\begin{array}{c}\text { Total titratable } \\
\text { acidity (\%) }\end{array}$ \\
\hline Goiás ${ }^{1}$ & $74.19^{a} \pm 9.75$ & $5.76^{a} \pm 0.26$ & $5.13^{\mathrm{a}} \pm 0.25$ & $16.43^{\mathrm{a}} \pm 4.33$ & $3.47^{b} \pm 0.00$ & $12.10^{b} \pm 0.29$ \\
\hline Tocantins $^{1}$ & $38.99^{b} \pm 4.85$ & $4.36^{\mathrm{b}} \pm 0.37$ & $3.98^{\mathrm{b}} \pm 0.11$ & $20.92^{\mathrm{a}} \pm 4.45$ & $3.73^{a} \pm 0.02$ & $10.84^{c} \pm 0.38$ \\
\hline Pará ${ }^{1}$ & $30.22^{\mathrm{c}} \pm 4.72$ & $4.47^{b} \pm 0.22$ & $3.67^{c} \pm 0.23$ & $21.22^{\mathrm{a}} \pm 6.69$ & $3.29^{c} \pm 0.00$ & $14.26^{a} \pm 0.20$ \\
\hline \multicolumn{7}{|c|}{ Data from the literature } \\
\hline $\begin{array}{l}\text { Santos et al. (2017) - } \\
\text { Amapá }\end{array}$ & 55.48 & 5.38 & 4.85 & 20.48 & 4.16 & - \\
\hline $\begin{array}{l}\text { Cameiro \& Cameiro } \\
\text { (2011)-Piauí }\end{array}$ & 33.7 & 5.3 & 3.9 & 11.0 & - & - \\
\hline $\begin{array}{l}\text { Barbosa et al. (2010) - } \\
\text { Roraima }\end{array}$ & 51.2 & 4.3 & 3.7 & 24.3 & - & - \\
\hline
\end{tabular}

${ }^{1}$ Results of the present study expressed as the mean \pm SD of three repetitions.

Means with the same letters in the same column present no statistical difference at $5 \%$ of probability by Tukey's test.

Table 2 Physical and chemical characteristics of the sweets elaborated with buriti pulps from three Brazilian States.

\begin{tabular}{lccccc}
\hline Characteristics $^{1}$ & Final mass $(\mathrm{g})$ & Yield $(\%)$ & $\begin{array}{c}\text { Soluble solids } \\
\left({ }^{\circ} \text { Brix }\right)\end{array}$ & $\mathrm{pH}$ & $\begin{array}{c}\text { Total titratable } \\
\text { acidity }(\%)\end{array}$ \\
\hline Goiás & $353.17^{\mathrm{a}} \pm 7.29$ & $70.63^{\mathrm{a}} \pm 1.46$ & $81.66^{\mathrm{a}} \pm 0.29$ & $3.57^{\mathrm{b}} \pm 0.0$ & $8.43^{\mathrm{a}} \pm 0.29$ \\
Tocantins & $368.17^{\mathrm{a}} \pm 7.42$ & $73.63^{\mathrm{a}} \pm 1.48$ & $82.66^{\mathrm{a}} \pm 0.58$ & $3.88^{\mathrm{a}} \pm 0.0$ & $7.03^{\mathrm{b}} \pm 0.00$ \\
Pará & $366.35^{\mathrm{a}} \pm 1.90$ & $73.23^{\mathrm{a}} \pm 1.26$ & $80.5^{\mathrm{b}} \pm 0.70$ & $3.43^{\mathrm{c}} \pm 0.0$ & $8.81^{\mathrm{a}} \pm 0.21$ \\
\hline
\end{tabular}

${ }^{1}$ Results of the present study expressed as the mean \pm SD of three repetitions.

Means with the same letters in the same column present no statistical difference at $5 \%$ of probability by Tukey's test.

The moisture, carbohydrates, and lipids contents of the buritis from Tocantis and Pará were similar. The values of lipids from both regions were twice those of the pulps from Goiás, justifying the great differences in total energy values between them (Table 3).

A lack of genetic uniformity between the trees and factors such as altitude, temperature, rainfall and soil could also have influenced the compositions of the fruits, since these factors control the availability of nutrients to the plants (Rossi et al., 2014; Urrego et al., 2016). At higher altitudes with milder temperatures, the plants take longer to complete the reproductive cycle, since the photosynthesis and respiration rates are lower (Laviola et al., 2008). 
Table 3 Proximate compositions $(\mathrm{g} / 100 \mathrm{~g})$ of the buriti pulps and sweets compared to the literature data.

\begin{tabular}{|c|c|c|c|c|c|c|c|}
\hline Characteristics & Moisture & $\begin{array}{l}\text { Crude } \\
\text { protein }\end{array}$ & Total lipids & $\begin{array}{l}\text { Fixed } \\
\text { mineral } \\
\text { residue }\end{array}$ & $\begin{array}{l}\text { Dietary } \\
\text { fiber }\end{array}$ & Carbohydrates & $\begin{array}{c}\text { Energetic } \\
\text { value } \\
(\mathrm{kcal} / 100 \mathrm{~g})\end{array}$ \\
\hline \multicolumn{8}{|l|}{ Buriti pulps } \\
\hline Goiás $^{1}$ & $70.00^{a} \pm 0.35$ & $1.85^{\mathrm{b}} \pm 0.01$ & $9.03^{b} \pm 0.19$ & $1.18^{\mathrm{b}} \pm 0.01$ & $7.17^{b} \pm 0.33$ & 10.60 & 131.07 \\
\hline Tocantis $^{1}$ & $56.91^{\mathrm{b}} \pm 1.65$ & $2.69^{a} \pm 0.12$ & $17.77^{a} \pm 0.54$ & $1.28^{a} \pm 0.01$ & $6.42^{c} \pm 0.22$ & 15.02 & 230.77 \\
\hline Pará$^{1}$ & $58.52^{\mathrm{b}} \pm 0.58$ & $2.14^{\mathrm{a} \pm 0.02}$ & $18.91^{\mathrm{a} \pm 0.48}$ & $1.04^{\mathrm{c}} \pm 0.00$ & $8.16^{a} \pm 0.38$ & 11.22 & 223.70 \\
\hline \multicolumn{8}{|c|}{ Data from the literature for buriti pulps } \\
\hline $\begin{array}{l}\text { Schiassi et al. (2018) - } \\
\text { São Paulo }\end{array}$ & 79.35 & 1.43 & 7.72 & 1.01 & 6.02 & 4.47 & 93.08 \\
\hline $\begin{array}{l}\text { Aguiar and Souza } \\
(2017) \text {-Amazonas }\end{array}$ & 55.00 & 2.35 & 22.17 & 1.61 & - & 18.87 & 284.40 \\
\hline $\begin{array}{l}\text { Sandri et al. (2017) - } \\
\text { Mato Grosso }\end{array}$ & 59.69 & 2.97 & 20.92 & 1.04 & 8.56 & 7.28 & 229.28 \\
\hline $\begin{array}{l}\text { Manhães \& Sabaa- } \\
\text { Srur(2011)-Pará }\end{array}$ & 62.93 & 2.10 & 13.85 & 0.94 & 5.17 & 8.25 & 166.36 \\
\hline $\begin{array}{l}\text { Cameiro \& Cameiro } \\
\text { (2011)-Caatinga }\end{array}$ & 54.35 & 1.30 & 18.16 & 0.66 & - & 25.53 & 270.00 \\
\hline $\begin{array}{l}\text { Mariath et al. (1989) - } \\
\text { Maranhão }\end{array}$ & 69.60 & 1.80 & 8.10 & 0.70 & 9.60 & 19.80 & 145.00 \\
\hline \multicolumn{8}{|l|}{ Buriti sweets } \\
\hline Goiás $^{1}$ & $14.08^{\mathrm{a}} \pm 0.30$ & $0.75^{\mathrm{c}} \pm 0.00$ & $7.69^{\mathrm{c}} \pm 0.27$ & $1.27^{b} \pm 0.05$ & $5.23^{b} \pm 0.14$ & 70.98 & 356.13 \\
\hline Tocantins ${ }^{1}$ & $11.42^{\mathrm{c}} \pm 0.44$ & $0.90^{\mathrm{b}} \pm 0.02$ & $11.74^{\mathrm{a}} \pm 0.24$ & $1.60^{\mathrm{a}} \pm 0.00$ & $4.68^{\mathrm{c}} \pm 0.02$ & 69.66 & 387.9 \\
\hline Pará $^{1}$ & $12.97^{\mathrm{b}} \pm 0.13$ & $1.21^{\mathrm{a}} \pm 0.05$ & $8.57^{b} \pm 0.12$ & $0.71^{\mathrm{c}} \pm 0.02$ & $6.10^{\mathrm{a}} \pm 0.18$ & 70.44 & 363.71 \\
\hline \multicolumn{8}{|c|}{ Data from the literature for buriti sweets } \\
\hline $\begin{array}{llr}\text { Mariath } & \text { et } & \text { al. } \\
(1989) & & - \\
\text { Maranhão } & & \\
\end{array}$ & 17.30 & 0.70 & 6.50 & 0.90 & 7.20 & 74.60 & 326.00 \\
\hline
\end{tabular}

The buritis from Goiás showed similar behaviors to those from São Paulo (Schiassi et al., 2018) and Maranhão (Mariath et al., 1989), with close values for the moisture, protein, total lipid and total energy. Whereas the buritis from Pará and Tocantins showed values closer to those of buritis from Amazonas (Aguiar \& Souza, 2017), Mato Grosso (Sandri et al.; 2017) and Pará (Manhães \& Sabaa-Srur, 2011) (Table 3). Thus, the proximities of values could be related to the origin of the fruits, since buritis harvested in the regions dominated by the Amazonian biome tended to show similar compositions, the same occurring in the regions dominated by the Savanna biome.

The sweet elaborated with buriti pulp from Pará had higher concentrations of protein and fiber. The sweets from Tocantins showed higher lipid concentrations, contributing to their higher total energy values, since the carbohydrate concentrations did not vary too much between the three regions. The results of only one study about buriti sweet, formulated in the state of Maranhão, were found in literature (Mariath et al., 1989). A comparison of the results obtained in that study with those of the present study showed higher protein and total lipid contents in the buriti sweets from Maranhão (Table 3).

The moisture, protein, total lipid and fiber contents showed significant decreases after processing to make the sweets. The prolonged heating and addition of sugar used to elaborate the sweets could have been the main causes of these results.

\section{b) Total phenolic compounds and antioxidant activity}

The buritis from Goiás showed higher total phenolic compound concentrations and antioxidant activities in the DPPH•, ABTS and FRAP assays than those from the other regions, for the pulps and sweets (Table 4). A significant positive correlation was observed between total phenolics and antioxidant capacity in all the assays (Figure 2). This indicated that the phenolic compounds were amongst the principal factors responsible for the antioxidant activity, as also observed by Piluzza and Bullitta (2011) on analyzing the correlation between the phenolic compound contents and the antioxidant activities in 24 vegetable species. 
Table 4. Antioxidant potential ( $\mu \mathrm{mol} \mathrm{TE} / \mathrm{g}$ fruit) and total carotenoids $(\mu \mathrm{g} / \mathrm{g})$ of the buriti pulps and sweets from different Brazilian regions, on a dry basis.

\begin{tabular}{|c|c|c|c|c|c|c|}
\hline \multirow{2}{*}{ Characteristic $^{1}$} & \multicolumn{3}{|c|}{ Pulp } & \multicolumn{3}{|c|}{ Sweet } \\
\hline & Goiás & Tocantins & Pará & Goiás & Tocantins & Pará \\
\hline $\mathrm{DPPH} \bullet$ & $561.73^{a} \pm 4.84$ & $167.76^{c} \pm 3.62$ & $210.60^{b} \pm 3.62$ & $34.59^{d} \pm 0.68$ & $24.46^{f} \pm 0.28$ & $30.34^{\mathrm{e}} \pm 0.36$ \\
\hline ABTS & $185.72^{a} \pm 9.01$ & $70.90^{c} \pm 3.53$ & $89.55^{b} \pm 3.01$ & $61.52^{\mathrm{d}} \pm 1.87$ & $44.77^{e} \pm 0.59$ & $55.35^{d} \pm 2.60$ \\
\hline FRAP & $176.06^{a} \pm 2.66$ & $55.76^{\mathrm{c}} \pm 1.52$ & $71.30^{\mathrm{b}} \pm 2.89$ & $24.91^{d} \pm 0.98$ & $13.55^{f} \pm 0.67$ & $18.60^{e} \pm 1.0$ \\
\hline $\begin{array}{l}\text { Total phenolic } \\
\text { compounds }\end{array}$ & $1652.94^{\mathrm{a}} \pm 29.06$ & $836.53^{c} \pm 37.13$ & $917.90^{b} \pm 49.43$ & $363.59^{d} \pm 16.28$ & $281.17^{\mathrm{e}} \pm 8.17$ & $245.83^{f} \pm 9.64$ \\
\hline Total carotenoids & $1166.89^{b} \pm 53.78$ & $1468.72^{a} \pm 67.96$ & $1209.20^{\mathrm{b}} \pm 49.65$ & $191.71^{d} \pm 6.47$ & $339.43^{c} \pm 9.00$ & $220.02^{d} \pm 3.79$ \\
\hline
\end{tabular}
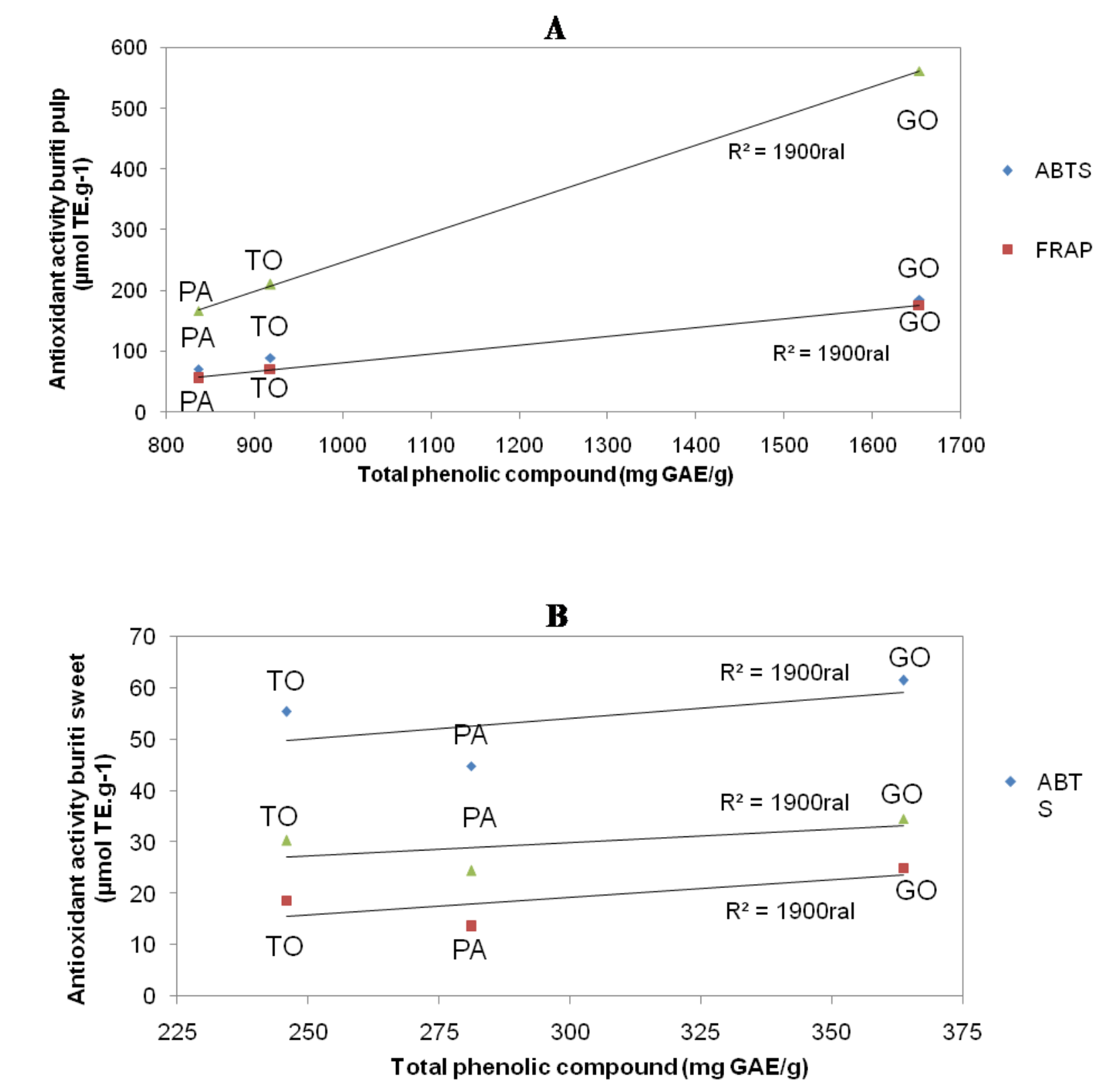

Figure 2 Relationship between the total phenolic compound composition and the antioxidant activity in the different trials for the buriti pulp (A) and sweet (B) from three Brazilian regions (dry basis).

GO: Goiás; TO: Tocantins; PA: Pará; ABTS: 2,2 azinobis (3-ethylbenzothiazoline-6-sulfonic acid); FRAP: $\mathrm{Fe}^{3}+$ reducing capacity; DPPH•:2,2-diphenyl-1-picryl-hydrazil. 
A significant positive correlation ( $r 60.95 ; p<0.05$ ) was observed between total phenolics and antioxidant capacity through the different methods applied

The total phenolic compound contents and antioxidant activities in the DPPH•, ABTS and FRAP assays reduced significantly in the sweets (Table 4). There was a reduction of about $80 \%$ in the phenolic compound concentrations for the sweets elaborated with fruits from Goiás, and a $75 \%$ reduction for those produced with native fruits from Tocantins and Pará.

The prejudicial effect of the elevated temperature on the total phenolic compound contents and the antioxidant activities might have justified these results (Chipururu et al., 2010). The cooking process may have been sufficient to inactivate the peroxidases that act as pro-oxidants, degrading the antioxidant compounds. However, cooking is also capable of favoring the formation of new compounds, such as Maillard reaction products, which have antioxidant activity, but only when the heat treatment is of low intensity and duration (Nicoli et al., 1999).

Considering the results on a dry basis (Table 4), the antioxidant capacity as determined by the DPPH• method for the three regions studied, was greater than that reported by Cândido et al., (2015) for buriti pulp from the Savanna of $123.28 \mu \mathrm{mol}$ of TE/g and of $20 \mu \mathrm{mol}$ of TE/g by (Gonçalves et al., 2010), and for exotic fruits such as camu-camu (141 $\mu \mathrm{mol}$ of TE/g) and cambuci (9.0 $\mu \mathrm{mol}$ of TE/g) (Genovese et al., 2008).

For the ABTS trial, the data reported by Contreras-Calderón et al. (2011) for fruits from the Colombian Amazon $(70.2 \mu \mathrm{mol}$ of $\mathrm{TE} / \mathrm{g}$ ) were higher than the results obtained in the present study for Goiás $(55.71 \mu \mathrm{mol}$ of TE/g), Tocantins $(30.52 \mu \mathrm{mol}$ of TE/g) and Pará $(37.14 \mu \mathrm{mol}$ of TE/g), on a wet basis. However, the results obtained for the native buriti pulp from Goiás presented higher values than those described by Cândido et al. (2015) for fruits from the same region $(46.63 \mu \mathrm{mol}$ of TE. $\mathrm{g}^{-1}$ ) and for fruits from the Amazon (33.02 $\mu \mathrm{mol}$ of TE/g). Also, the results for the antioxidant activity as determined by the ABTS in the present study for buriti pulps were higher than those reported for other fruits such as sweet passion fruit $(10.84 \mu \mathrm{mol}$ of $\mathrm{TE} / \mathrm{g})$ and jenipapo $(7.31 \mu \mathrm{mol}$ of TE/g) (Souza et al., 2012).

On a wet basis, the antioxidant capacity determined for the buriti pulp from Tocantins (24.01 $\mu \mathrm{mol}$ of TE/g) and from Pará $(29.57 \mu \mathrm{mol}$ of TE/g) by the FRAP method were analogous to those obtained for pulp originating from the Colombian Amazon $(27.80 \mu \mathrm{mol}$ of TE/g) and from the Brazilian Amazon (26.95 $\mu \mathrm{mol}$ of TE/g) (Cândido et al., 2015). However, the buriti pulp from Goiás showed a much higher result $(52.82 \mu \mathrm{mol}$ of $\mathrm{TE} / \mathrm{g})$ than those reported for the buriti pulps from the Colombian Amazon (Contreras-Calderón et al., 2011) and from the Brazilian Savanna (38.64 $\mu \mathrm{mol}$ of TE/g) (Cândido et al., 2015). In addition this result was higher than that reported for traditional fruits such as guava $(39.9 \mu \mathrm{mol}$ of TE/g) and peach $(8.88 \mu \mathrm{mol}$ of TE/g) (Contreras-Calderón et al., 2011).

On a wet basis, the total phenolic compound concentrations found in the Goiás pulp (495.87 mg GAE/100 g) were similar to the values reported for fruits in the same region (435.08 mg GAE/100 g) (Cândido et al., 2015). Similarly, native pulps from Tocantins (360.08 mg GAE/100 g) and from Pará (402.98 mg GAE/100 g), as analyzed by Koolen et al. (2013), presented results similar to those observed for fruits from the Brazilian Amazon (378.07 mg GAE/100 g). However, these results were higher than those found in the Colombian Amazon (281 mg GAE/100 g) (Contreras-Calderón et al., 2011) and in the north and northeast of Brazil (108.1 mg GAE/100 g) (Barreto et al., 2009).

\section{c) Total carotenoids}

The pulps and sweets from Tocantins presented higher values for carotenoids than any of the other pulps analyzed (Table 4). The production of carotenoids can be directly affected by the availability of nutrients, type of soil, water stress, temperature, incidence of solar light, period when cultivated and period when harvested (Gross, 1991). Thus, the fruits from Tocantins could have been produced under more appropriate conditions, favoring the concentration and chemical profile of the carotenoids.

The heat treatment and addition of sugar in the elaboration of the sweets reduced the carotenoid concentration by about $80 \%$. This can be justified by the highly unsaturated structure of the carotenoids, which made them susceptible to degradation by the action of enzymes, heat, light, 
and oxidation (Britton, 1992).

Despite the fact that the carotenoid losses from the sweets were high, the contents found in the ready-to-eat foods could still be considered important for the health, since foods with more than $20 \mu \mathrm{g} / \mathrm{g}$ of carotenoids can be considered rich in this nutrient (Rodrigues-Amaya et al., 2008). In addition, of all the Brazilian foods analyzed by these authors, buriti was the food with the highest concentration of $\beta$-carotene, also showing the advantage of having a high lipid content, which favors the absorption and bioavailability of the carotenoids (Mezzomo \& Ferreira, 2016).

The native buriti pulp from Goiás presented a total carotenoid concentration of $349.93 \mu \mathrm{g} / \mathrm{g}$, on a wet basis, higher than the values reported by Cândido, Silva and Agostine-Costa (2015) of $311.3 \mu \mathrm{g} / \mathrm{g}$ for fruits from the same region, but lower than those of the fruits from Goiás studied by Lima et al. (2009) of $446.0 \mu \mathrm{g} / \mathrm{g}$. However the results observed for the buriti pulp from Tocantins of $632.20 \mu \mathrm{g} / \mathrm{g}$ were higher than those observed for buriti pulps from Pará $(528.6 \mu \mathrm{g} / \mathrm{g}$ ) (Cândido et al., 2015), Amazon (513.87 $\mu \mathrm{g} / \mathrm{g}$ ) (Rosso \& Mercadante, 2007) and from the north and northeast of Brazil $(142 \mu \mathrm{g} / \mathrm{g}$ ) (Barreto et al., 2009). Fruits such as pequi $(4 \mu \mathrm{g} / \mathrm{g})$ and physalis $(17 \mu \mathrm{g} / \mathrm{g})$ (Barreto et al., 2009) showed total carotenoid contents below those reported in our study.

\section{CONCLUSIONS}

The origin of the fruit of buriti influenced the content of chemical compounds along with the antioxidant activity. Although variations have been observed among fruits from different regions, as well as losses due to the processing of sweets, such foods can still be considered good dietary sources of bioactive compounds, especially carotenoids. The high lipid content of these fruits reinforces their functional potential, once this component helps the bioavailability of carotenoids. Further studies are suggested to evaluate the phenolic and carotenoid compounds profile of pulp and buriti sweet, moreover the bioaccessibility of these compounds.

\section{ACKNOWLEDGEMENTS}

The authors a gratefully acknowledge CNPq (Brazilian research supporting foundation) for granting the research scholarship.

\section{REFERENCES}

Aguiar, J.P.L., \& Souza, F.C.A. (2017). Dehydration and spraying of buriti pulp (Mauritia flexuosa L.): shelf-life evaluation. Revista Brasileira de Fruticultura, 39(14), 1-7. http://dx.doi.org/10.1590/0100-29452017034

Association of Official Agricultural Chemists - AOAC. (2012). Official methods of analysis of the Association of the Agricultural Chemists, Gaithersburg: AOAC

Barbosa, R.I., Lima, A.D., \& Júnior-Mourão, M. (2010). Biometria de frutos de buriti (Mauritia flexuosa L. f. - Arecaceae): produção de polpa e óleo em uma área de savana em Roraima. Ciência and Desenvolvimento, 5(10), 71-85.

Barreto, G.P.M., Benassi, M. T., \& Mercadante, A. Z. (2009). Bioactive compounds from several tropical fruits and correlation by multivariate analysis to free radical scavenger activity. Journal of the Brazilian Chemical Society, 20(10), 1856-1861.

Benzie, I.F.F., \& Strain, J.J. (1996). The ferric reducing ability of plasma (FRAP) as a measure of antioxidant power: the FRAP assay. Analytical Biochemistry, 239, 70-76. https://doi.org/10.1006/abio.1996.0292

Bligh, E.G., \& Dyer, W.J. (1959). A rapid method of total lipid extraction and purification. Canadian Journal of Biochemistry and Physiology, 37, 911-917. https://doi.org/10.1139/059-099

Brand-Williams, W., Cuvelier, M.E., \& Berset, C. (1995). Use of a free radical method to evaluate antioxidant activity. Lebensmittel-Wissenschaft + [i.e.und] Technologie, 28, 25-30. https://doi.org/10.1016/S0023-6438(95)80008-5

Britton, G. (1992). Carotenoids. In: HENDRY, G. F., Natural foods colorants (pp.197-224). New York: G.F. Blackie. 
Cândido, T.L.N., Silva, M.R., \& Agostini-Costa, T.S. (2015). Bioactive compounds and antioxidant capacity of buriti (Mauritia flexuosa L.f.) from the Cerrado and Amazon Biomes. Food Chemistry, 15(177), 313-319. https://doi.org/10.1016/j.foodchem.2015.01.041

Carneiro, T.B., \& Carneiro, J.G.M. (2011). Frutos e polpa desidratada buriti (Mauritia flexuosa I.): aspectos físicos, químicos e tecnológicos. Revista Verde, 6(2), 105-111.

Chipururu, B., Muchuweti, M. \& Manditseraa, F. (2010). Effects of thermal treatment on the phenolic contente and antioxidante activity of some vegetables. Asian Journal of Clinical Nutrition, 2(3), 93-100. https://doi.org/10.3923/ajcn.2010.93.100

Contreras-Calderón, J., Calderón-Jaimes, L. Guerra-Hernández \& E. García-Villanova, B. (2011). Antioxidant capacity, phenolic content and vitamin $C$ in pulp, peel and seed from 24 exotic fruits from Colombia. Food Research International, 44, 2047-2053. https://doi.org/10.1016/j.foodres.2010.11.003

Genovese, M.I., Pinto, M.S., Gonçalves, A.E.S.S., \& Lajolo, F.M. (2008). Bioactive compounds and antiantioxidant activity of exotic fruits and commercial frozen pulps from Brazil. Food Science and Technology International, 14(3), 207-214. http://dx.doi.org/10.5935/1806-6690.20180070

Gomes, L.R.P., Lopes, M.T.G., Bentes, J.L.S., Barros, W.S., Costa Neto, P.Q. \& Contim, L.A.S. (2011). Diversidade genética em populações naturais de Buriti (Mauritia flexuosa L. f.). Crop Breeding and Applied Biotechnology, 11, 216-223. http://dx.doi.org/10.1590/S198470332011000300003

Gonçalves, A.E.S.S., Lajolo, F.M., \& Genovese, M.I. (2010). Chemical Composition and Antioxidant/Antidiabetic Potential of Brazilian Native Fruits and Commercial Frozen Pulps. Journal of Agricultural and Food Chemistry, 58(8), 4666-4674. http://dx.doi.org/10.1021/jf903875u

Gross, J. (1991). Pigments in vegetables: chlorophylls and carotenoids. New York: Van Nostrand Reinhold.

IAL - Instituto Adolfo Lutz. (2008). Métodos físico-químicos para análise de alimentos. Brasília: Ministério da Saúde.

Koolen, H.H.F., Silva, F.M.A., Gozzo, F.C., Souza, A.Q.L., \& Souza, A.D.L. (2013). Antioxidant, antimicrobial activities and characterization of phenolic compounds from buriti (Mauritia flexuosa L. f.) by UPLC-ESI-MS/MS. Food Research International, 51(1), 467-473. https://doi.org/10.1016/j.foodres.2013.01.039

Laviola, B.G., Martinez, H.E.P., Salomão, L.C.C., Cruz, C.D., Mendonça, S.M., \& Rosado, L. (2008). Acúmulo em frutos e variação na concentração foliar de NPK em cafeeiro cultivado em quatro altitudes. Bioscience Journal, 24, 19-31.

Lima, A.L.S., Lima, K.S.C., Coelho, M.J., Silva, J.M., Godoy, R.L.O., \& Pacheco, S. (2009). Avaliação dos efeitos da radiação gama nos teores de carotenóides, Ácido ascórbico e açúcares do fruto buriti do brejo (Mauritia flexuosa L.). Acta Amazônica, 39(3), 649-654. http://dx.doi.org/10.1590/S0044-59672009000300020

Manhães, L.R.T., \& Sabaa-Srur, A.U.O. (2011). Centesimal composition and bioactive compounds in fruits of buriti collected in Pará. Ciência e Tecnologia de Alimentos, 31(4), 856-863. http://dx.doi.org/10.1590/S0101-20612011000400005

Mariath, J.G.R., Lima, M.C.C., \& Santos, L.M.P. (1989). Vitamin A activity of buriti (Mauritia vinifera Mart) and its effectiveness in the treatment and prevention of xerophthalmia. The American Journal of Clinical Nutrition, 49, 849-853. http://dx.doi.org/10.1093/ajcn/49.5.849

Medeiros, R. (2011). Gastronomia do Cerrado. Brasília: Fundação Banco do Brasil.

Mezzomo, N. \& Ferreira, S.R.S. (2016). Carotenoids functionality, sources, and processing by supercritical technology: A review. Journal of Chemistry, Article ID 3164312 , http://dx.doi.org/10.1155/2016/3164312 
Milanez, J.T., Neves, L.C., Colombo, R.C., Shahab, M. \& Roberto, S.R. (2018). Bioactive compounds and antioxidant activity of buriti fruits, during the postharvest, harvested at different ripening stages. Scientia Horticulturae, 227, 10-21. https://doi.org/10.1016/j.scienta.2017.08.045

Milanez, J.T., Neves, L.C., Silva, P.M.C., Bastos, V.J., Shahab, M., Colombo, R.C. ,\& Roberto, S.R. (2016). Pre-harvest studies of buriti (Mauritia flexuosa L.F.), a Brazilian native fruit, for the characterization of ideal harvest point and ripening stage. Scientia Horticulturae, 202, 77-82. https://doi.org/10.1016/j.scienta.2016.02.026

Saito, C.H. (Coord.). (2006). Educação ambiental PROBIO. Brasília: Departamento de Ecologia da Universidade de Brasília/Ministério do Meio Ambiente.

Neri-Numa, I.A., Sancho, R.A.S., Pereira, A.P.A., \& Pastore, G.M. (2018). Small Brazilian wild fruits: nutrients, bioactive compounds, health-promotion properties and commercial interest. Food Research International, 103, 345-360. https://doi.org/10.1016/j.foodres.2017.10.053

Piluzza, G. \& Bullitta, S. (2011). Correlations between phenolic content and antioxidant properties in twenty-four plant species of traditional ethnoveterinary use in the Mediterranean area. Pharmaceutical Biology, 49(3), 240-247. https://doi.org/10.3109/13880209.2010.501083.

Prosky, L., Asp, N., Schweizer, T.F., Devries, J.W., \& Furda, I. (1988). Determination of insoluble, soluble, and total dietary fiber in foods and food products: interlaboratory study. Journal of Association of Official Analytical Chemists, 71(5), 1017-1023. https://doi.org/10.5740/jaoacint.CS2011_25

Re, R., Pellegrini, N., Proteggente, A., Pannala, A., \&Yang, M.;Rice-Evans, C. (1999). Antioxidant activity applying an improved ABTS radical cátion decolorization assay. Free Radical Biology and Medicine, 26(9), 1231-1237. https://doi.org/10.1016/S0891-5849(98)00315-3

Rodriguez-Amaya, D. B. (2001). A guide to carotenoid analysis in foods. Washington: International Life Sciences Institute (ILSI) Press.

Rodrigues-Amaya, D.B., Kimura, M. \& Amaya-Farfan, J. (2008), Fontes brasileiras de carotenoides: tabela brasileira de composição de carotenoides em alimentos. Brasília: Ministério do Meio Ambiente, Secretária da Biodiversidade e Florestas.

Rossi, F.S., Rossi, A.A.B., Dardengo, J.F.E., Brauwers, L.R., Silva, M.L., \& Sebbenn, A. M. (2014). Diversidade genética em populações naturais de Mauritia flexuosa L. f. (Arecaceae) com uso de marcadores ISSR. Scientia Forestalis, 42(104), 631-639.

Rosso, V.V. \& Mercadante, A.Z. (2007). Identification and quantification of carotenoids, by HPLCPDA-MS/MS, from Amazonian fruits. Journal of Agricultural and Food Chemistry, 55(13), 5062 5072. https://doi.org/10.1021/jf0705421

Roucoux, K.H., Lawson, I.T., Jones, D.T., Baker, T.R., Coronado, E.N.H., Gosling, W.D., \& Lahteenoja, O. (2013). Vegetation development in an Amazonian peatland. Palaeogeography, Palaeoclimatology, Palaeoecology, 374, 242-255. https://doi.org/10.1016/j.palaeo.2013.01.023

Sandri, D.O., Xisto, A.L.R.P., Rodrigues, E.C., Morais, E.C., \& Barros, W.M. (2017). Antioxidant activity and physicochemical characteristics of buriti pulp (Mauritia flexuosa) collected in the city of Diamantino - MTS. Revista Brasileira de Fruticultura, 39(3), 1-7. http://dx.doi.org/10.1590/0100-29452017864

Santos, M.F.G., Alves, R.E., Brito, E.S., Silva, S.M., \& Silveira, M.R.S. (2017). Quality characteristis of fruits and oils of palms native to the Brazilian Amazon. Revista Brasileira de Fruticultura, 39, 1-6. http://dx.doi.org/10.1590/0100-29452017305

Schiassi, M.C.E.V., Souza, V.R., Lago, A.M.T., Campos L.G. \& Queiroz, F. (2018). Fruits from the Brazilian Cerrado region: physico-chemical characterization, bioactive compounds, antioxidant activities, and sensory evaluation. Food Chemistry, 245, 305-311. https://doi.org/10.1016/j.foodchem.2017.10.104

Silva, L.A.G.C. (2007). Biomas presentes no estado do Tocantis. Brasília: Câmara dos Deputados. Journal of Bioenergy and Food Science. Vol.7: e2792019JBFS, 2020 
Souza, V.R., Pereira, P.A.P., Queiroz, F., Borges, S.V., \& Carneiro, J.D.S. (2012). Determination of bioactive compounds, antioxidant activity and chemical composition of Cerrado Brazilian fruits. Food Chemistry, 134, 381-386. https://doi.org/10.1016/j.foodchem.2012.02.191

Urrego, L.E., Galeano, A., Peñuela, C., Sánchez, M., \& Toro, E. (2016). Climate-related phenology of Mauritia flexuosa in the Colombian Amazon. Plant Ecology, 217, 1207-1218.

Vera, R., Naves, R.V., Nascimento, J.L., Chaves, L.J., Leandro, W.M., \& Souza, E.R.B. (2005). Caracterização física de frutos do pequizeiro (Caryocar Brasiliense Camb.) no estado de Goiás. Pesquisa Agropecuária Tropical, 35(2), 71-79.

Virapongse, A. (2017). Social mechanisms and mobility: buriti palm (Mauritia flexuosa) extractivism in Brazil. Human Ecology, Vol. 45, 119-129. https://doi.org/10.1007/s10745-016-9887-9 